\title{
Cinnamon Firewood as a Biofuel for Electricity Generation
}

\section{J. Karunanayake}

Abstract: Biomass based electricity generation is now a well-established concept and in Sri Lanka, gliricidia has been accepted as the most suitable biofuel. Considering this and the fertilizer displacement benefits, the Government of Sri Lanka has given prominence for cultivating gliricidia on a large scale by declaring it as the fourth plantation crop.

The objective of this paper is to discuss the use of cinnamon firewood as a biofuel for electricity generation. Thus, analysing cinnamon wood's heat characteristics, examining its availability and assessing its potentiality for electricity generation are matters of paramount importance.

Cinnamon wood is the residue left from peeling the cinnamon bark. The villagers in cinnamon growing areas were the first to identify the superior heat generating properties of cinnamon wood as compared to other types of firewood. However, its effectiveness as a biofuel for electricity generation could be best assessed by comparing its heat characteristics and other properties with those of gliricidia.

Cinnamon grows in most parts of the country and cinnamon wood is available year-round as a byproduct. The process is sustainable, and the 32,345 ha of cinnamon plantations presently available have the potential to add at least $80 \mathrm{GWh}$ annually to the national grid. Hence, there may not be a need to devote land purely for cultivation of biofuels.

Keywords: Cinnamon, Gliricidia, Calorific value, Moisture content, Electricity generation

\section{Introduction}

The first ever proposal to generate electricity in Sri Lanka with cultivated biomass was presented around 30 years back at a seminar organized by the Institution of Engineers, Sri Lanka. Not many took this proposal seriously. However, those who were convinced of the concept continued to push forward the new idea relentlessly. To prove their point, these green energy promoters commissioned a $4 \mathrm{~kW}$ gasifier based electricity generating unit that used gliricidia as the fuel. This was followed by the installation and commissioning of a $35 \mathrm{~kW}$ gasifier driven electricity generating unit by LTL Ltd. In this backdrop, green energy enthusiasts highlighted the possibilities and advantages of using biomass as an alternative for fossil fuels to generate electricity and gliricidia has so far been accepted as the best biomass fuel for electricity generation. Taking all these into consideration, the Government of Sri Lanka (GOSL) in 2005, declared gliricidia as the country's fourth plantation crop. ([1]Abegunwaerdana [1\}).

The objective of this paper is to introduce cinnamon firewood as a biomass fuel for electricity generation, discuss its properties and compare the same with those of gliricidia to focus the attention of the authorities on the more productive use of this resource.

\section{Biomass Fuel Based Electricity Generation}

Biomass based electricity generation is a sustainable process which is being practiced in many parts of the world. The type of biomass fuel used varies from power station to power station and the most common are wood chips, bagasse and garbage. The first grid connected electricity generating plant that used biomass (gliricidia) as fuel in Sri Lanka was established in Walapane by LTL. About the same time, green energy promoters started lobbying for better tariffs for biofuel based electricity generation in view of their high operating costs. The GOSL which positively responded to this lobbying even at that time, now offers attractive purchase tariffs for such generation. Today, around 25MW of biofuel based electricity generation plants are connected to the national grid.

Eng. J. Karunanayake, B.Sc.Eng., C.Eng., MIE(SL), MIET Consultant Electrical Engineer.

Email:jkarun@gmail.com 
Uneconomic purchase tariffs and various concessions can make any type of generation financially viable, but the question that arises is whether the electricity industry or the country could reap benefits from this type of electricity generation, as ultimately it is the electricity consumers and the general public who will have to bear the burden of implementing/sustaining unviable projects.

Hence the immediate need is to find ways and means of reducing the operating costs of biofuel based generation if it is to become competitive in the presence of conventional resource based generation. The first step towards this goal is the identification of the right kind of biomass fuel, which ideally should:

a) Have superior heat generating characteristics,

b) be available in large quantities,

c) be available right throughout the year and preferably within an area of 10-25 $\mathrm{km}$ from the generating station,

d) be preferably a byproduct of another manufacturing process so that no extra effort would be required in sourcing the raw material, and

e) be able to be kept in storage for long periods

The research/analysis/investigations that have been carried out in the past have shown that cinnamon wood satisfies all the conditions mentioned above. The residue from the cinnamon leaf oil distillation process which is a by-product of that process could also be used as a supplement and would even be cheaper than the cinnamon wood itself.

\subsection{Cinnamon Wood as Fuel}

Cinnamon is native to Sri Lanka and is one of the earliest known spices used by mankind. In the ancient days, there had been cinnamon forests in Sri Lanka and the Sinhala kings had ruthlessly exploited these forests to fulfill the obligations forced on them by Portuguese traders. The Dutch in 1658 secured the cinnamon trade and in 1767 commenced large scale planned cinnamon cultivation. They enacted legislation for this purpose and by 1850, the total extent under cinnamon had reached about 40,000 acres ([1]Raveendranetal [2]). As at present, nearly 32,345 ha $(80,000$ acres) are under cinnamon cultivation. Of the 25 districts in Sri Lanka, cinnamon is grown as a commercial crop in 14 districts and Table 1 gives the details. These include Nuwaraeliya as well as Hambanthota, which are respectively the wettest and the driest districts of Sri Lanka. No other proof, perhaps, is required to show that cinnamon can be grown as a commercial crop in any part of Sri Lanka. Galle and Matara have the largest extents of land under cinnamon cultivation. The adjoining districts Hambanthota, Kalutara and Rathnapura come next.

\subsubsection{Cinnamon Tree, its Uses and Cinnamon Farmers}

Cinnamon is world famous as a spice. Cinnamon bark, bark oil and leaf oil are the main products obtained from the cinnamon tree. These are also being used as raw materials in many industries such as soap, pharmaceuticals, cosmetics, food preservatives, insecticides etc. Sri Lanka's export earnings from cinnamon products exceeded Rs. 19 billion in 2015.

\begin{abstract}
Villagers of Sri Lanka consider cinnamon stems(after peeling) as the best firewood available to them. A stem once peeled,weighs around $500 \mathrm{~g}-900 \mathrm{~g}$. Traders visit the cinnamon growers, collect these stems and transport them to small towns and cities. Their customers are households and small commercial establishments such as bakeries. These traders are very selective when they choose the stems and would buy only those having diameters exceeding $2.5 \mathrm{~cm}$ or so. The farmers use the rest in their homes for cooking and fencing or let them go waste.
\end{abstract}

Table 1 - Extent of cinnamon cultivation in Sri Lanka (2015)

\begin{tabular}{|l|l|l|l|l|l|}
\hline District & Extent (ha) & Extent (acres) & District & Extent (ha) & Extent (acres) \\
\hline Kandy & 130 & 321 & Hambanthota & 3258 & 8,047 \\
\hline & & & & & \\
\hline Matale & 335 & 827 & Colombo & 242 & 598 \\
\hline Nuwaraeliya & 35 & 86 & Gampaha & 278 & 687 \\
\hline Kurunegala & 166 & 410 & Kalutara & 3397 & 8,391 \\
\hline Badulla & 195 & 482 & Ratnapura & 4174 & 10,310 \\
\hline Monaragala & 93 & 230 & Kegalle & 266 & 657 \\
\hline Galle & 11246 & 27,778 & Other & 5 & 12 \\
\hline Matara & 8522 & 21,049 & Total & 32,342 & 79,885 \\
\hline
\end{tabular}


Nevertheless, this process has established a network of collectors/transporters of cinnamon firewood. By selling cinnamon firewood, cinnamon farmers can earn an additional income, though the price they get from intermediaries is aslow as Rs2-3 per stem or Rs. $3-4.50 / \mathrm{kg}$. More than $90 \%$ of cinnamon growers are small holders having land extents less than 2.5 ha. If cinnamon firewood could be put into better use as a biofuel, the low income earners in the cinnamon growing areas would benefit while at the same time helping the country to reap rich dividends from a resource which is still grossly underutilized.

\subsubsection{Cinnamon Plant}

Cinnamon in its original wild form is a large tree growing to a height of 10-12 meters or more, with a stem girth of 20-30 cm When cultivated as an economic crop, the tree Is coppiced, trained and maintained to form a bush of convenient height. Generally, eight to ten stems from each plant are allowed to grow until they attain a sufficient girth of at least the size of a thumb.

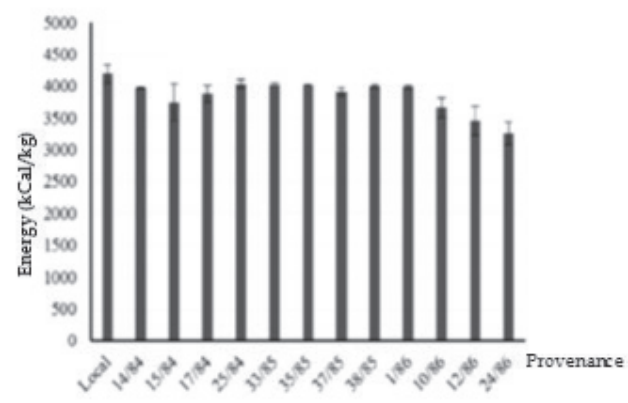

Figure 1 - Calorific value of different Gliricidia provenance

\subsubsection{Harvesting of Cinnamon}

Harvesting of cinnamon is carried out throughout the year excluding January/February and August/September. Cinnamon stems of sufficient girth are cut off from the bush and their bark is peeled off from which quills are made. Peeling is done using traditional methods. Mechanization and/or automation will give a big boost to the industry. Normal practice is to do harvesting at 8 month intervals, but growers who use better crop management techniques, do the harvesting at intervals of six months.

\subsubsection{Cinnamon as a Fuel Source}

People in cinnamon growing areas use cinnamon wood as a fuel in cooking. This has been the practice for several centuries, may be even for more than thousands of years. Having correctly identified its heat generating properties which are superior to those of any other type of firewood, these villagers have got the habit of preserving cinnamon wood for useas fuel on important occasions such as almsgivings or weddings.

\subsubsection{Calorific Value and Moisture Content}

To analyze the suitability of cinnamon wood as a fuel for electricity generation, a sample was tested at the Industrial Technology Institute (ITI) and the findings are reproduced in Table 2.

Table 2 - Calorific value of cinnamon wood

\begin{tabular}{|l|l|l|}
\hline Item & $\begin{array}{l}\text { Val } \\
\text { ue }\end{array}$ & $\begin{array}{l}\text { Conditions under which } \\
\text { tests were carried out }\end{array}$ \\
\hline $\begin{array}{l}\text { Calorific } \\
\text { value }\end{array}$ & $\begin{array}{l}4829 \\
\text { Cal } \\
/ \mathrm{g}\end{array}$ & $\begin{array}{l}\text { Moisture free basis, 1 } \\
\text { week after peeling the } \\
\text { bark }\end{array}$ \\
\hline
\end{tabular}

Source: ITI Test report SS2340-2006

One way of assessing the effectiveness of cinnamon wood as a bio fuel is to compare its heat generating and other relevant properties with those of gliricidia, presently considered as the best biofuel in Sri Lanka.

An extensive study to determine these properties of gliricidia has been carried out by the Coconut Research Institute (CRI)([3] Attapattu,etal 2017[3])and the bar-chart of the calorific values of the different gliricidia provenances as determined by this study is reproduced in Figure 1. Based on its calorific value and the other properties such as moisture content, biomass yield, wood density etc., Type 15/84 could be considered as the best gliricidia provenance for electricity generation. It has a calorific value of 3750 $\mathrm{kCal} / \mathrm{kg}$, whereas that of "local landrace" is $4200 \mathrm{kCal} / \mathrm{kg}$. (Please see.2.1.5.1)

The calorific value of cinnamon $(4829 \mathrm{kCal} / \mathrm{kg})$ is much higher than that of the best provenance of gliricidia $(3750 \mathrm{kCal} / \mathrm{kg})$ and "local landrace" (4200kCal/kg).

\subsubsection{Moisture Content and its Relevance}

When assessing the heat producing capability of any fuel, its calorific value determined on a " $100 \%$ dry basis" is not the only parameter to be considered. Moisture content also becomes equally important. The heat produced by burning $1 \mathrm{~g}$ of wood having a calorific value of $\mathrm{C} \mathrm{Cal/g}$ and a moisture content of $\mathrm{n} \%$ will be $C *(1-n / 100)$ Calories. Moisture present in wood lowers its realizable calorific value.

During the combustion process, energy will be released from wood and a part of it will be spent for moisture evaporation and this energy will not be available for the intended use ([1],Krajnc 2015 [5]). 
Table 3 - Gliricidia provenances used for the study

\begin{tabular}{|l|l|l|l|l|l|}
\hline OFI Indent No & Provenance & Origin & OFI Indent No & Provenance & Origin \\
\hline $14 / 84$ & Ratalhuleu & Guatemala & $38 / 85$ & Playa Azul & Mexico \\
\hline $15 / 84$ & Gualan & Guatemala & $1 / 86$ & Mariora & Venezuela \\
\hline $17 / 84$ & Monterrico & Guatemala & $10 / 86$ & La Garita & Honduras \\
\hline $25 / 84$ & Masaguara & Honduras & $12 / 86$ & $\begin{array}{l}\text { Playa } \\
\text { Tamarindo }\end{array}$ & Costa Rica \\
\hline $33 / 85$ & Los Amates & Mexico & $24 / 86$ & Ponte Zuela & Columbia \\
\hline $35 / 85$ & $\begin{array}{l}\text { Sanmateo Del } \\
\text { Mar }\end{array}$ & Mexico & Local & Local landrace & Sri Lanka \\
\hline $37 / 85$ & N/A & N/A & & & \\
\hline
\end{tabular}

Source: Gliricidia in Sri Lanka ([1]Gunasena 1997 [4])

\subsubsection{Moisture Content of Peeled Cinnamon Wood}

An extract from the ITI test report on the moisture content of cinnamon wood is presented in Table 4.

Table 4 - Moisture content of cinnamon wood

\begin{tabular}{|l|l|l|}
\hline Item & Value & $\begin{array}{l}\text { Conditions under } \\
\text { which tests were } \\
\text { carried out }\end{array}$ \\
\hline $\begin{array}{l}\text { Moisture } \\
\text { content }\end{array}$ & $15.94 \%$ & $\begin{array}{l}\text { One week after } \\
\text { peeling the bark }\end{array}$ \\
\hline
\end{tabular}

Source: ITI Test report SS2340-2006

All types of wood generally have a high moisture content of around $60 \%$ at the time of harvesting, and would drop to a lower value, after the wood has been allowed to dry for a considerable period of time. Most of this moisture is stored in the bark and with its removal, the stem would immediately be relieved of a large quantity of moisture.

The removal of the bark would also permit the firewood to absorb heat more efficiently from the sun and shed some of the moisture stored in it. The removal of the bark, especially from a stem having a small girth like in cinnamon or gliricidia is a painstaking, time consuming and a costly exercise.

In this context, cinnamon differs from the other types of wood. The most valuable part of the cinnamon tree is its bark. In fact, the cinnamon tree is grown solely for the purpose of extracting the bark. This primary requirement of removing the bark is taken care of during cinnamon peeling process, thus making any further processing of the residual stem totally unnecessary, before it is put to use as a biofuel. Cinnamon wood that is peeled or from which its bark has been removed is available in plenty in cinnamon growing areas.
2.1.5.3 Moisture Content of Gliricidia Wood Figure 2 shows the moisture contents of the gliricidia provenances[3]found in the CRI study and it could be seen that the moisture contents of all provenances are in the same range. These tests have been done on fresh samples. When exposed to the atmosphere, their moisture contents could get lowered due to sun drying.

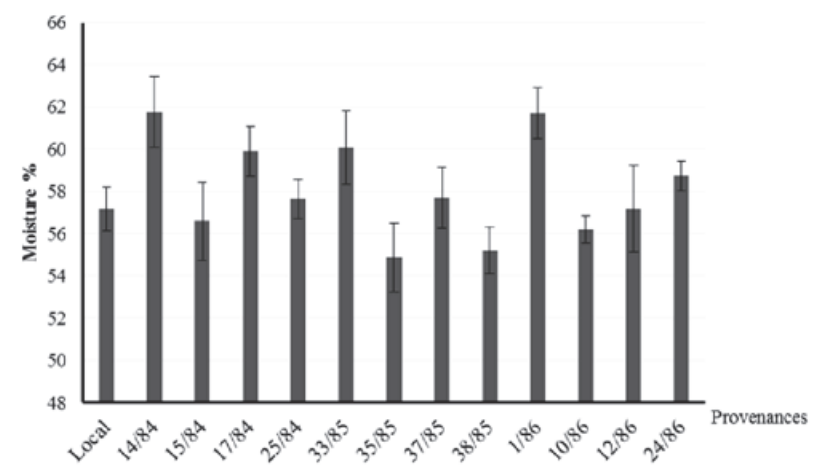

Figure 2 - Moisture contents of different Gliricidia provenances

However, tests carried by biofuel researchers have shown that gliricidia wood's moisture content will remain in the range of $28 \%$ $33 \%$ (average $30 \%$ )even after it has been subjected to an artificial drying process.

Cinnamon wood's superiority can be assessed from its moisture content, which is $15.94 \%$ after it has been dried naturally. This is against the $30 \%$ moisture content found in glricidia even after undergoing a forced drying process.

\section{Fresh Biomass Yield}

Fresh biomass yield and wood available for energy extraction are two other important parameters used in the assessment of the heat storage properties of wood. 


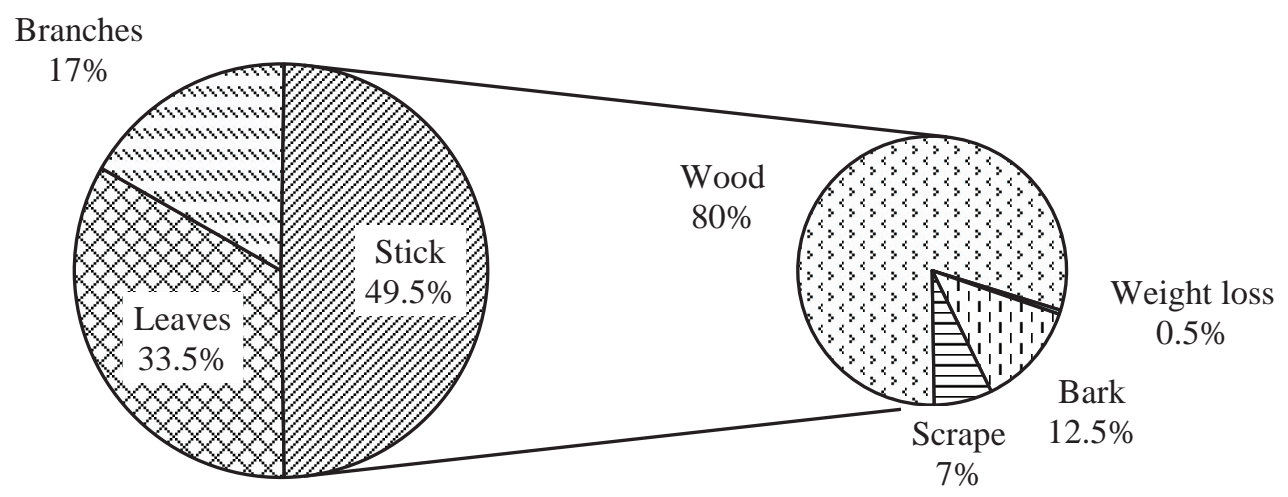

Figure 3 - Relationship among the weights of cinnamon stem parts

\subsection{Cinnamon}

The relationships that have been established among the various parts of the cinnamon stem ([3]Ranasinghe;etal,[6])are reproduced in Figure 3.

The relationship between fresh biomass weight and the dry bark is defined by Equation (1) below.

$Y=0.0486 X+0.00346$

where

$Y=$ Yield of dry bark in kilograms

$X=$ Weight of stems in kilograms

Fresh bio-mass (stems with leaves, moisture etc.)

Weight $=\frac{(Y-0.00346)}{0.0486} \mathrm{~kg}$

Weight of wood (inclusive of moisture)

$$
=\frac{(Y-0.00346) *(49.5 \% * 80 \%)}{0.0486}
$$

Total production of dry cinnamon bark for the Year $2015=17,707 \mathrm{mt}$

Average yield of dry bark for cinnamon $(\mathrm{Y})$

Using Equation (3)

$$
\begin{aligned}
& =17,707^{*} 10^{3} / 32,342 \quad \mathrm{~kg} / \mathrm{ha} \\
& =547.5 \mathrm{~kg} / \mathrm{ha}
\end{aligned}
$$

Weight of wood inclusive of moisture

$$
\begin{aligned}
& =\frac{(547-0.00346) *(49.5 \% * 80 \%)}{0.0486} \mathrm{~kg} / \mathrm{ha} \\
& =4,457 \mathrm{~kg} / \mathrm{ha}
\end{aligned}
$$

\subsection{Gliricidia}

The fresh bio-mass yields of the different gliricidia provenances as determined by the CRI study[3] are presented in Table 5. Assuming that the weight relationships of cinnamon with stems, leaves, branches and wood are valid for gliricidia as well, the wood weight inclusive of moisture (per ha)for gliricidia was calculated.

\subsection{Net Energy Available}

Using the calorific values and the moisture contents determined, the net energy available in cinnamon wood and gliricidia (15/84 and Local landrace) were calculated and these are shown in Table 6. The effect of the moisture content becomes a significant factor in this exercise, as part of the energy generated has to be used to bring up the temperature of the moisture from atmospheric temperature to the boiling temperature of $100^{\circ} \mathrm{C}$ and thereafter to evaporate it.

Net energy available/ha for cinnamon is higher than that of "local landrace", but is lower than that of $15 / 84$, the imported variety. It should be noted that the same weight, stems, leaves, branches relationships of cinnamon were applied for gliricidia as well, which may present an inflated value for gliricidia, as its wood density is lower than that of cinnamon.

\subsection{Transportation and Storage \\ 3.4.1 Transportation}

The economics of transporting fuel wood can be understood by considering the related costs in terms of Calories. Peeled cinnamon wood weighing $1 \mathrm{~kg}$ would contain $159.4 \mathrm{~g}$ of moisture and would have a heat energy reserve of $(4829 *(1-15.94 \%))=4059 \mathrm{kCal}$, whereas $1 \mathrm{~kg}$ of gliricidia will have almost twice that amount of moisture $(300 \mathrm{~g})$ and only $70 \%$ of the heat energy $(4200 *(1-$ $30 \%))=(2940 \mathrm{kCal})$. Hence in terms of $\mathrm{Cal} / \mathrm{km}$, the transport of cinnamon will be much cheaper than the transport of gliricidia. 
Table 5 - Fresh biomass yield variation among different gliricidia provenances

\begin{tabular}{|c|c|c|c|c|c|c|c|}
\hline \multirow[t]{2}{*}{$\begin{array}{l}\text { Proven } \\
\text { ance }\end{array}$} & \multicolumn{2}{|c|}{$\begin{array}{l}\text { Fresh biomass yield } \\
\text { of } 12 \text { month after } \\
\text { pruning }\end{array}$} & \multirow{2}{*}{$\begin{array}{l}\text { Wood+Moistu } \\
\text { re }=49.5 \% \text { * } \\
80 \% * \text { fresh } \\
\text { biomass yield } \\
\text { tons/ha }\end{array}$} & \multirow[t]{2}{*}{$\begin{array}{l}\text { Proven } \\
\text { ance }\end{array}$} & \multicolumn{2}{|c|}{$\begin{array}{l}\text { Fresh biomass yield } \\
\text { of } 12 \text { month after } \\
\text { pruning }\end{array}$} & \multirow{2}{*}{$\begin{array}{l}\text { Wood +moisture } \\
=49.5 \% * 80 \% * \text { fres } \\
\text { h biomass yield } \\
\text { tons } / \text { ha }\end{array}$} \\
\hline & $\mathrm{kg} /$ tree & tons/ha & & & $\mathrm{kg} /$ tree & tons/ha & \\
\hline $15 / 84$ & 33.9 & 26.5 & 10.5 & $1 / 86$ & 16.2 & 12.7 & 5.0 \\
\hline $17 / 84$ & 13.3 & 10.4 & 4.1 & $10 / 86$ & 8.5 & 6.6 & 2.6 \\
\hline $25 / 84$ & 13.8 & 10.8 & 4.3 & $12 / 86$ & 14.3 & 11.2 & 4.4 \\
\hline $33 / 85$ & 5.7 & 4.5 & 1.8 & $24 / 86$ & 21.5 & 16.8 & 6.7 \\
\hline $35 / 85$ & 14.6 & 11.4 & 4.5 & Local & 17.8 & 14.0 & 5.544 \\
\hline $37 / 85$ & 18.1 & 14.1 & 5.6 & & & & \\
\hline
\end{tabular}

Table 6 - Calculation of net heat energy available/ hectare

\begin{tabular}{|c|c|c|c|c|c|c|}
\hline $\begin{array}{l}\text { Fuel wood } \\
\text { type }\end{array}$ & $\begin{array}{l}\text { Weight } \\
\text { of fuel } \\
\text { wood } \\
\text { with } \\
\text { moisture } \\
(\mathrm{kg})\end{array}$ & $\begin{array}{l}\text { Calorific } \\
\text { value } \\
\text { moisture } \\
\text { free basis } \\
(\mathrm{kCal} / \mathrm{kg})\end{array}$ & $\begin{array}{l}\text { Moisture } \\
\text { content } \\
(\%)\end{array}$ & $\begin{array}{l}\text { Heat } \\
\text { generated } \\
(\mathrm{kCal}) \\
(1)\end{array}$ & $\begin{array}{l}\text { Heat used for } \\
\text { evaporating } \\
\text { moisture } \\
(\mathrm{kCal}) / \mathrm{ha} \\
(2)\end{array}$ & $\begin{array}{l}\text { Net } \\
\text { energy } \\
\text { available } \\
(\mathrm{kCal}) / \mathrm{ha} \\
(1)-(2)\end{array}$ \\
\hline $\begin{array}{l}\text { 15/84 } \\
\text { Gliricidia }\end{array}$ & 10,500 & 3750 & 30 & $\begin{array}{l}10,500 * 3750 \\
*(1-30 \%) \\
=27,562,500\end{array}$ & $\begin{array}{l}10,500 * 30 \% * 10^{3}((10 \\
0-30)+540) / 10^{3} \\
=1,921,500\end{array}$ & $25,641,000$ \\
\hline $\begin{array}{l}\text { Local } \\
\text { Gliricidia }\end{array}$ & 5,544 & 4200 & 30 & $\begin{array}{l}5,544 * 4,200 * \\
(1-30 \%) \\
=16,299,360\end{array}$ & $\begin{array}{l}5,544 * 30 \% * 10^{3 *}((100 \\
-30)+540) / 10^{3} \\
=1,014,552\end{array}$ & $15,284,808$ \\
\hline Cinnamon & 4,457 & 4,829 & 15.94 & $\begin{array}{l}4457 * 4829 * \\
(1-15.94 \%) \\
=18,092,110\end{array}$ & $\begin{array}{l}4457^{*} 15.94 \% * 10^{3}(10 \\
0-30)+540) / 10^{3} \\
=433,372\end{array}$ & $17,658,738$ \\
\hline
\end{tabular}

\subsubsection{Storage}

Based on the experience of villagers, peeled cinnamon wood can be kept in storage without being attacked by insects. This can be attributed to its low moisture content (and possibly high volatile content). On the other hand, the inherent problem with gliricidia is that it is prone to attacks from insects. The experience at Walapane confirmed the villagers observations in this regard.

\section{Cinnamon Leaves}

A large percentage of cinnamon leaves are left in the plantations during harvesting as only a portion would be used for oil extraction by steam distillation. A sample of the residue obtained from a distillation plant was tested at the ITI laboratories and the results obtained are reproduced in Table 7 .

Table 7 - Calorific value and moisture content of cinnamon leaves

\begin{tabular}{|l|l|}
\hline $\begin{array}{c}\text { Moisture } \\
\text { content }\end{array}$ & $\begin{array}{l}\text { Calorific value (moisture } \\
\text { free basis) Cal/g }\end{array}$ \\
\hline $11.7 \%$ & 4565 \\
\hline
\end{tabular}

Source :ITI Test report no - SS3288 2006
It is customary to use this residue as fuel to produce steam for distillation. However, if efficiency improvements of this process could be carried out, part of the residue could be used as an alternative fuel for electricity generation. Cinnamon oil extraction should be developed as a cottage industry at village level. The distillation residue can also be used as a fuel source either by grinding or forming same into briquettes and this task could also be encouraged to be performed by the villagers themselves.

\section{Conversion to Electrical Energy}

\subsection{Cinnamon Wood Required to Generate 1kWh}

The basic data assumed and the calculations carried out to determine the amount of cinnamon wood and gliricidia wood required to produce $1 \mathrm{kWh}$ are shown in Table 8 and Table 9 respectively. Properties of locally available gliricidia were used for this analysis, as $15 / 84$ is available only as a test plot. 
Table 8 - Basic data

\begin{tabular}{|l|l|l|l|}
\hline Parameter & Value & Parameter & Value \\
\hline Purchasable wood - \% wood available & $70 \%$ & Latent heat (Cal/g) & 540 \\
\hline Temperature of water $0 \mathrm{C}$ & 28 & $\mathrm{kWh} /$ Calorie & $0.11632 \times 10^{-5}$ \\
\hline Boiler efficiency & $75 \%$ & Calorific value (Cal/g) - Cinnamon & 4829 \\
\hline Turbine cycleefficiency & $25 \%$ & Moisture content - Cinnamon & $15.94 \%$ \\
\hline Generator efficiency & $95 \%$ & Calorific value (Cal/g) - Gliricidia & 4,200 \\
\hline Plant factor & $85 \%$ & Moisture content -Glricidia & $30 \%$ \\
\hline Power factor & $95 \%$ & & \\
\hline
\end{tabular}

Table 9 - Calculation of cinnamon/gliricidia wood required to generate $1 \mathrm{kWh}$

\begin{tabular}{|l|l|l|l|l|}
\hline & \multicolumn{2}{|c|}{ Cinnamon } & \multicolumn{2}{l|}{ Gliricidia Local Landrace } \\
\hline Item & Formula & Result & Formula & Result \\
\hline Overall efficiency & $75 \%^{*} 95 \%^{*} 25 \%$ & $17.8 \%$ & $75 \%^{*} 9 \%^{*} 25 \%$ & $17.8 \%$ \\
\hline Available heat energy (Cal/g) & $4829^{*}(1-15.94 \%)$ & 4059 & $4200^{*}(1-30 \%)$ & 2940 \\
\hline $\begin{array}{l}\text { Total energy required to evaporate the } \\
\text { moisture content -(Cal) }\end{array}$ & $\begin{array}{l}0.1594^{*}(100- \\
28+540)\end{array}$ & 97.55 & $\begin{array}{l}0.3^{*}(100- \\
28+540)\end{array}$ & 183.6 \\
\hline $\begin{array}{l}\text { Energy available for conversion/g } \\
\text { (Cal) }\end{array}$ & $4059.25-97.55$ & $3,961.7$ & $4200-183.6$ & 2756 \\
\hline kWh produced through a kg of wood & $\begin{array}{l}3,961.7^{*}\left(0.11632^{*} 10^{-}\right. \\
5)^{*} 10^{*} 17.8 \%\end{array}$ & 0.82 & $\begin{array}{l}27566^{*}(0.11632 \\
\left.\times 10^{-5}\right)^{*} 10^{3} \\
{ }^{*} 17.8 \%\end{array}$ & 0.57 \\
\hline $\begin{array}{l}\text { Fuel wood required to produce 1kWh } \\
(\mathrm{kg})\end{array}$ & $1 / 0.85$ & 1.22 & $1 / 0.57$ & 1.75 \\
\hline
\end{tabular}

Cinnamon wood is a by-product, whereas gliricidia has to be harvested specifically to be used as fuel wood for electricity generation. Hence it is obvious that the cost of using gliricidia for electricity generation as a biofuel is much higher than with cinnamon firewood. Considering the present prices of cinnamon firewood, the cost of delivering $1 \mathrm{~kg}$ of cinnamon wood may not exceed Rs. 7.00. Hence, the fuel cost of cinnamon wood based generation can be as low as Rs $(1.22 * 7)=$ Rs. 8.54 .

\subsection{Electrical Energy Output and Plant Capacities}

Calculations/results presented in Table 10 show that the estimated annual electrical energy output and plant capacities from purchasable cinnamon wood would be in the range of $80 \mathrm{GWh}$ and $11 \mathrm{MW}$ respectively as at present. Considering mainly the limitations on transportation, it is proposed to establish three electricity generating stations targeting the cinnamon wood in the respective districts.

a) Matara and Hambanthota (5MW)

b) Galle (4 MW)

c) Kalutara and Rathnapura (3MW)

These need to be developed as distributed generation plants. Since mini hydro plants are almost non-existent in the major cinnamon growing areas, GSS or MV line capacities will not cause much problems to the developers. It should be noted that the above mentioned capacities have been determined using only cinnamon wood with no consideration given to the availability of cinnamon distillate residue.

In Table 10, for comparison purposes, calculations and results for electrical energy outputs are also shown for a similar extent of land under gliricidia cultivation. It could be seen that the electrical energy potential and the plant capacities have dropped to around 68GWh and 9.6MW respectively.

\section{Conclusion}

Cinnamon wood has a huge potential for use as a biofuel for electricity generation. Currently (2015) in Sri Lanka,there are 32,342 haunder cinnamon cultivation, 30,756 ha of which are in major cinnamon growing areas. Even if it is assumed that the collectable quantity of cinnamon wood for power generation is $70 \%$, its electrical energy producing potential will be around $80 \mathrm{GWh}$ with a capacity addition of around 11MW.

This will be in addition to earning Rs. 19 billion from the export of cinnamon products and the injection of nearly Rs. $700 \mathrm{~m}$ to the rural economy through the sale of cinnamon firewood (@Rs 5/kg), 
Table 10 -Estimation of electrical energy generation potential of the existing cinnamon plantations

\begin{tabular}{|c|c|c|c|c|c|}
\hline \multicolumn{2}{|c|}{$\begin{array}{l}\text { Land under cinnamon } \\
\text { cultivation }\end{array}$} & $\begin{array}{l}\text { Weight of } \\
\text { available wood } \\
\text { (with moisture) } \\
\text { (b) } \\
b=(a) * 4457\end{array}$ & $\begin{array}{l}\text { Purchasable } \\
\text { Wood } \\
\text { (c) } \\
c=(b) * 70 \%\end{array}$ & $\begin{array}{l}\text { Electrical output } \\
\text { possible }(\mathrm{d}) \\
d \\
=(c) * .82 * 10^{-3}\end{array}$ & $\begin{array}{l}\text { Plant capacity } \\
\text { (e) } \\
e \\
=\frac{d}{8760 * P l . F * P F}\end{array}$ \\
\hline District & ha $=(a)$ & $(\mathrm{kg})$ & $(\mathrm{kg})$ & MWh & MW \\
\hline Matara $+\mathrm{H}^{\prime}$ tota & 11919 & $53,123,088$ & $37,186,162$ & 30,524 & 4.32 \\
\hline Galle & 11246 & $50,123,521$ & $35,086,465$ & 28,800 & 4.07 \\
\hline $\mathrm{K}^{\prime}$ tara+R pura & 7571 & $33,744,014$ & $23,620,810$ & 19,389 & 2.74 \\
\hline Total & 30,736 & $136,990,624$ & $95,893,437$ & 78,712 & 11.13 \\
\hline \multicolumn{6}{|c|}{ Had these cinnamon lands were planted with gliricidia, the energy potentials } \\
\hline & a & $b=(a) * 5544$ & $c=(b) * 70 \%$ & $d=(c) * .571 * 10^{-3}$ & $e=\frac{d}{8760 * P l . F * P F}$ \\
\hline Matara $+\mathrm{H}^{\prime}$ tota & 11919 & $66,078,936$ & $46,255,255$ & 26,416 & 3.73 \\
\hline Galle & 11246 & $62,347,824$ & $43,643,477$ & 24,925 & 3.52 \\
\hline $\mathrm{K}^{\prime}$ tara+R'pura & 7571 & $41,973,624$ & $29,381,537$ & 16,780 & 2.37 \\
\hline Total & 30,736 & $170,400,384$ & $119,280,269$ & 68,121 & 9.63 \\
\hline
\end{tabular}

The harvesting process of any type of firewood will involve felling trees, lopping off branches, collection and drying etc., which all will be at a cost. These costs will be non existent for cinnamon, as all costs involved will be a part of the peeling process. Had these 32,345ha been cultivated with gliricidia, the main product would have been firewood, which would come at a higher cost, with a lower electrical energy output and no export earnings whatsoever. Unfortunately other benefits of gliricidia such as fertilizer displacement or its use as animal feed could not be quantified in this study due to the nonavailability of credible information.

Cinnamon as a biofuel is superior to gliricidia. However, gliricidia is abundantly available in all parts of the country and is a proven biofuel. Hence it should be used for power generation, as long as costs remain competitive. Nevertheless, embarking on large scale gliricidia plantations needs to be carefully analyzed. Cinnamon can be grown in any part of Sri Lanka, even as an intercrop with rubber or coconut. The feasibility of growing cinnamon in the lands earmarked for gliricidia cultivation needs to be investigated.

Electricity generation using cinnamon wood should in no way be considered as a substitute for coal or other conventional resources and should be developed as distributed generation. In major cinnamon growing areas, mini-hydro plants are almost non-existent. Hence the capacity of GSS or MV lines will not be ahindrance to the developers.
The demand for cinnamon is continuously growing. If peeling process is automated/mechanized and the right kind of patronage comes from the GOSL, there could be a dramatic turnaround in the cinnamon industry and huge increase in the output of cinnamon firewood can be expected.

\section{References}

1. Gliricidia- Fourth Plantation Crop of Sri Lanka, Asoka Abeygunawardana.

2. Cinnamon and Cassia The geneus Cinnmomum, $\mathrm{P}$ N Raveendran, K NimalBabu and M Shylaja. P9,

3. Potential of Gliricidia sepiumas a Fuel Wood Species for Sustainable Energy Generation in Sri Lanka. AAJ Atapattu, DKNG Pushpakumara, WMD Rupasinghe, SHS Senarathne and SAST Raveendra CRI, LunuwilaE Faculty of Agriculture, University of Peradeniya,

4. Gliricidia in Sri Lanka HPM Gunsena University of Peradeniya Oxford Forestry Institute (UK)

5. Wood fuels handbook Dr. Nike KrajncFAO of The United Nations Pristina, 2015.

6. Relationship of Bark Yield, Bark and Leaf Oil Contents with Stick Parameters of True Cinnamon(CinnamomumzeylanicumBlume)RADRA Ranasinghe, KGG Wijesinghe and IK Ruwansiri cinnamon Research Station, Pothupitiya. 